\title{
69- William Blake’in Yankıyan Yeşillik adlı eserinde romantik öğeler
}

Engin BÖLÜKMEŞE ${ }^{1}$

\section{Halil ÖZDEMİR²}

APA: Bölükmeşe, E.; Özdemir, H. (2021). William Blake’in Yankıyan Yeşillik adlı eserinde romantik öğeler. RumeliDE Dil ve Edebiyat Araştırmaları Dergisi, (25), 1120-1129. DOI: 10.29000/rumelide.1037129.

\section{$\ddot{O} \mathbf{z}$}

Romantizm kavramının ortaya çıkışı, başlangıç ve bitiş periyoduyla ilgili karmaşıklık söz konusu olsa da yöntem açısından Klasisizm'e karşı sav barındıran bir edebi akımı temsil etmektedir. Yazarlar dönemin başlangıcında romantik olarak adlandırılmasalar da bir süre sonra romantik dönem kategorisinde yer almışlardır. Romantik bir şair olan William Blake, Romantizmin unsurlarını şiirlerinde canlı bir şekilde yer vermiştir. Şiirlerinde Romantizm akımında yer alan hayal gücü, öznellik, düşünce ve ifade özgürlüğü ve doğanın idealleştirilmesi ile karakterize edilen tüm fenomenler yoğun bir şekilde yer almaktadır. Şiirlerinde hayal gücünü ve vizyonerliğini somutlaştırarak kullanmaktadır. Romantik dönem şairlerinin birçoğu, İngiltere ile Fransa arasındaki savaştan ve Fransız Devrimi'nden oldukça etkilenmiştir. Blake de bu etkilenmelerin ortasında kalarak, eski klasik dönem fikirlerine karşı eserlerini derin bir ilhamla kaleme almıştır. Bu çalışmada Blake’in özgür, dramatik ve romantik ruh haliyle yazmış olduğu Yankıyan Yeşillik adlı şiirinde yer alan romantik unsurlar incelenecektir. Eser, Romantik akımda yer alan hayal gücü, mistisizm, sembolizm, özgürlük sevgisi, çocukluğa verilen önem, doğa, pastoral ortam ve lirizm çerçevesinde analiz edilecektir.

Anahtar kelimeler: Romantizm, Willliam Blake, Yankıyan Yeşillik, edebiyat, şiir

\section{Romantic Elements in William Blake's The Ecchoing Green}

\begin{abstract}
The emergence of the concept of romanticism represents a literary movement that has an argument against Classicism in terms of method, although there is controversy about its beginning and ending period. Although the authors were not defined as Romantic at the beginning of the era, they took part in the Romantic era category after a while. William Blake, a Romantic poet, vividly included elements of Romanticism in his poems. All the phenomena characterized by imagination, subjectivity, freedom of thought and expression, and idealization of nature in the Romanticism movement are heavily featured in his poems. He used his imagination and visionary in his poems through embodiment. Many of the poets of the Romantic era were greatly influenced by the war between England and France and the French Revolution. Blake was also influenced and wrote his works against the old classical era ideas with a deep inspiration. This study focuses on the Romantic elements in Blake's poem The Ecchoing Green, which he wrote in a free, dramatic, and romantic mood. The poem will be
\end{abstract}

Doç. Dr., Eskişehir Osmangazi Üniversitesi, Fen Edebiyat Fakültesi, Karşılaştırmalı Edebiyat Bölümü (Eşkişehir, Türkiye), enginb@gmail.com ORCID ID: 0000-0002-6482-7512 [Araştırma makalesi, Makale kayıt tarihi: 21.09.2021kabul tarihi: 20.12.2021; DOI: 10.2900o/rumelide.1037129]

Doktora Öğrencisi, Eskişehir Osmangazi Üniversitesi, Sosyal Bilimler Enstitüsü, Karşılaştırmalı Edebiyat ABD (Eskişehir, Türkiye), halilozdemireu@gmail.com ORCID ID: 0000-0003-0935-9047

\section{Adres $\mid$ Address}

RumeliDE Dil ve Edebiyat Araşttrmaları Dergisi Osmanağa Mahallesi, Mürver Ciçeği Sokak, No:14/8 Kadıköy - İSTANBUL / TÜRKIYE 34714 e-posta: editor@rumelide.com

RumeliDE Journal of Language and Literature Studies

Osmanağa Mahallesi, Mürver Çiçeği Sokak, No:14/8

Kadıköy - ISTANBUL / TURKEY 34714

tel: $+905057958124,+902167730616$

e-mail: editor@rumelide.com,

phone: +90 5057958124 , +90 2167730616 
analysed within the framework of imagination, mysticism, symbolism, love of freedom, importance given to childhood, nature, pastoral environment, and lyricism in the Romantic movement.

Keywords: Romanticism, William Blake, The Ecchoing Green, literature, poetry

\section{Giriş}

Romantizm akımı hayal gücüne ve öznelliğine, düşünce ve ifade özgürlüğüne ve doğanın idealleştirilmesine dayalı olarak karakterize edilen bir olgudur. William Lehen Pheleps, Romantizmin hem özgün hem de yeterli bir tanımını yapmaya yönelik herhangi bir girişimin, mutlaka başarısızlıkla sonuçlanacağını ifade ederek Romantizm bir konuya değil, yönteme uygulanır der. Pheleps, ilk bakışta Romantizmi tanımlayabileceklerini düşünen birçok kişi gördüğünü işin tahlil/çözümleme/analize geldiğinde bunu gerçekten yapabilen birini hiç rastlamadığının ifade etmektedir (Pheleps, 2012, s. 1-2). Michael Löwy ve Robert Sayre'de benzer şekilde Romantizm ile ilgili yapılan çalışmaların sınırlı ve kısmi olduğunun (özellikle XIX yy.) altını çizerek genel olarak Romantizm olgusunun yalnızca sanatsal ve edebi yanını ele alarak global bir romantizm bakış açısına sahip olmadıklarını dolayısıyla önemli bir boşluğun ortaya çıktığını Romantizm olgusunun gerçek kapsamını ve çeşitliliğini kapsayan global bir analizin bulunmadığını ifade etmektedir (Löwy \& Sayre, 2015, s. 27). Hakan Aksakal Romantizm kavramına ve anlaşılmasına benzer bir tanımın yanı sıra dikkat çekici hususlara yermektedir:

Romantizmi, bir çerçevenin içine bütünüyle sığdırıp, ona dair hiçbir şeyi dışarıda bırakmayarak tanımlamak mümkün gözükmemekle birlikte, bu yöndeki çeşitli girişimler başlangıç için bir kanaat verecek zenginliktedir. Romantizm birçok farklı olguyu bünyesinde bulunduran; bunları bazen çelişkileriyle, bazen de paralellikleriyle bir araya getiren hayli geniş, biraz da muhayyel, bir kavramdır (Aksakal, 2015, s. 15).

Aksakal'a göre Romantik akım son derece girift ve çapraşık bir örüntüye sahip olmakla beraber müşterek olarak bir tanımı ortaya konamamıştır (Aksakal, 2015, s. 15). Romantik dönem, tarihsel periyodunun belirsizliğinden edebi açıdan terimsel tanımının zorluğuna kadar birçok güçlüğü içinde barındıran bir edebi akımı temsil etmektedir.

Romantik akımın bir temsilcisi olarak yaşamı boyunca büyük ölçüde tanınmayan Blake, daha sonra hayal gücüne verdiği önem, mistisizmde ve sembolizmde, özgürlük sevgisinde, insani sempatisinde, çocukluğu idealleştirmesinde, pastoral ortamın şiirlerinde kullanmasıyla Romantik dönemin şiir ve görsel sanatlar tarihinde çı̆̆ır açan bir figür haline gelmiştir. "Yirminci yüzyılın büyük bir bölümünde, bilim adamları dönemin beş şairi; Wordsworth, Coleridge, Byron, Percy Shelley ve Keats’i seçtiler ve Blake’i gecikmeli bir şekilde altıncı yaparak eklediler ve şairlerin eserlerinin temelinde birleşik bir Romantizm kavramları inşa ettiler" (Greenblatt \& Abrams, 2005, s. 1). Blake geç bile olsa hem ün açısından hem de yaşadığı dönemin temsilcileri arasında yer almayı başarmıştır. Şiirlerinde sosyal konuları ele alan Blake, çocuk imgelerini sosyal protesto amaçlı bir sembol olarak kullanmaktadır. Çocuklar masumiyetin ve geleceğin birer sembolü olarak onun şiirlerinde bir anahtar görevi görmektedir. Sosyal düzendeki adaletsizlik, sanayi devriminin doğa ile mücadelesinin neden olduğu yıkıma vurgu yaparak toplumun masum kurbanları olan çocuklara atıflarda bulunmaktadır. Yankıyan Yeşillik şiiri ile insan zihninde en hassas ve masum sembolü olarak gördüğü çocukluğu ve onları bekleyen karanlık geleceği "On the darkening Green" "kararan yeşillik" ifadesini kullanarak dikkat çekmeye çalışmıştır. Bu bağlamdan yola çıkarak çalışmamızda Blake’in dizelerinde geçen ve gerçek hayatta yer alan hem eski kuşak hem de yeni nesil çocukların yaşamına dönük öngörü ve hayal dünyasının yansımaları olan romantik öğeler tespit ve analiz edilmeye çalışılacaktır. Söz konusu şiirde tespit edilen romantik öğelerin romantik akımın özelliklerini ne ölçüde taşıdığı irdelenecek ve elde

RumeliDE Dil ve Edebiyat Araştırmaları Dergisi Osmanağa Mahallesi, Mürver Çiçeği Sokak, No:14/8 Kadıköy - İSTANBUL / TÜRKIYE 34714 e-posta: editor@rumelide.com tel: +90 5057958124, +90 2167730616
Address

RumeliDE Journal of Language and Literature Studies

Osmanağa Mahallesi, Mürver Çiçeği Sokak, No:14/8

Kadıköy - ISTANBUL / TURKEY 34714

e-mail: editor@rumelide.com,

phone: +90 505 7958124, +90 2167730616 
edilen tespitler ve bulguların ışığında romantik unsurlar Blake’in şiir anlayışı ve perspektifinden değerlendirilmeye çalışılacaktır.

\section{William Blake (28 Kasım 1757 -12 Ağustos 1827)}

Londra doğumlu William Blake İngiliz Gravür(resim) sanatının ve Romantik akımın temsilcilerinden biridir. Londralı bir perakende tuhafiyecisi olan James Blake'in oğlu olan William Blake, 28 Kasım 1757'de ailenin üçüncü çocuğu olarak dünyaya gelir (Ackyord, 1995, s. 17). Blake çocukluğun daha ilk dönemlerinde sanata olan ilgisini ve kapasitesini gösterir. 4 Ağustos 1772 yllında daha on dördüne girdiğinde, gravürcüde çıraklık yapmıştır (Bentley, 2001, ss. 21-42). Çıraklık yıllarından sonra eğitimini Royal Academy (Kraliyet Sanat Akademisi'nde) tamamlar³ ve hayatının geri kalanında yoksulluk içinde, sadık bir eşin yardımıyla bir baskı ve gravür atölyesi tutarak kendi hayatını idame ettirmeye çalışır. Kendi gravürleri arasında en iyi bilineni, Chaucer'n Canterbury Pilgrims adlı ünlü resmidir. Eserlerinin büyük bir kısmı şiir ve düzyazıdan oluşan bir dizi kehanetler kitabından, kısmen dehadan, ancak dengesiz dehadan ve neredeyse anlaşılmaz eserlerden ibarettir. On üç yaşını geçmeden bestelediği bazı lirik şiirleri, başka hiçbir esere benzememekte ve bazıları en yüksek kalitede eserlerden oluşmaktadır.

Ĕ̆itimsiz bir yazar olarak yetkin bir gravürcü, özgün ve güçlü bir tasarımcı, grafik fikirlerinin mucidi, dahiyane, çekici ve şaşırtan kehanetleriyle güçlü bir eleştirel kimliğe sahip olan Blake’in şiirleri, vefatından sonrasına kadar neredeyse tamamen göz ardı edilir. Şiir kitaplarının hemen hemen hiçbiri hayattayken dikkat çekmemesi ve o dönem yapılan birkaç geçici değerlendirme, eserlerinin dikkate alınmamışlığını ve özgünlüğünü ortaya koymaktadır (Bentley, 1975, s. 1).

Farklı bir mizaca sahip olsa da bütünüyle dünyevi olmayan ve açıç̧ası anormal bir şair, birçok bakımdan tüm romanistlerin en uç noktalarından bir şair olarak bilinmektedir (Fletcher, 2002, s. 113). Kendisi “İngiliz Mistik Şairi” olarak da bilinir. Kendi dünyasında yaşayan ve çok güçlü dini duygulara sahip bir sanatçıdır. Akademilerin resim sanatlarını küçümsemesi nedeniyle birçok insan ona deli gözüyle bakıyordu. Tabi ona deli denmesinin tek sebebi bu değildi. O her açıdan diğer insanlardan farklıydı. Onu tanıyan dostlarından biri şöyle yazmış" Garip, ama zararsız biri...”4 Şair, Ressam, Grafiker olarak vizyoner şiirler yazmıştır. Önemli eserleri arasında Songs of Innocence and of Experience, The Tyger yer almaktadır.

On iki yaşında şiir yazmaya başlayan Blake, Thomas Paine ve Mary Wollstonecraft gibi zamanının önde gelen radikal düşünürleriyle ilişkili olan nonkonformist (toplum kurallarına ve geleneklere uymayan/ Anglikan kilisesine bağlı olmayan) bir kişidir. 18. yüzyıl neoklasik geleneklerine meydan okuyarak hem şiirlerini hem de imgelerini yaratırken hayal gücünü akla üstün tutup ve ideal formların doğa gözlemlerinden değil, içsel vizyonlardan inşa edilmesi gerektiğini öne sürer. Bir şiirinde, "Bir sistem yaratmalıyım ya da başka bir adamın kölesi olmalıyım" ifadelerine yer verir. "The French RevolutionFransiz Devrimi” (1791), "America, a Prophecy-Amerika bir Kehanet”) (1793), "Visions of the Daughters of Albion- Albion'un-Kizlarının Vizyonu” (1793) ve "Europe, a Prophecy-Avrupa bir Kehanet” (1794) gibi eserler onun İngiliz monarşisine ve genel olarak 18. yüzyll siyasi ve sosyal tiranlığına karşı olduğunun göstergesidir.5 Geleneksel şiirsel formlara ve tekniklere karşı duran, hayal gücüne akıldan çok değer veren birisi olmuştur.

https://www.biography.com/writer/william-blake Erişim Tarihi: 20.09.2021.

https://www.tarihlisanat.com/william-blake-kimdir-hayati-ve-sanati/ adresinden alındı Erişim Tarihi:20.09.2021. https://poets.org/poet/william-blake Erişim Tarihi: 20.09.2021.

Adres | Address

RumeliDE Dil ve Edebiyat Araştırmaları Dergisi Osmanağa Mahallesi, Mürver Çiçeği Sokak, No:14/8 Kadıköy - ÍSTANBUL / TÜRKIYE 34714 e-posta: editor@rumelide.com

RumeliDE Journal of Language and Literature Studies Osmanağa Mahallesi, Mürver Çiçeği Sokak, No:14/8

Kadıköy - ISTANBUL / TURKEY 34714

tel: +90 505 7958124, +90 2167730616 phone: +90 505 7958124, +90 2167730616 


\section{İngiliz Romantizm akımı}

Romantik dönem, sosyal ve ekonomik devrimlerle birlikte edebi bir devrimin yaşandığı bir dönemdir. Bazı edebiyat tarihi eserlerinde Romantik döneme "Devrim Çă̆ı" denmektedir (Kaya \& Kardaş, 2019, s. 92). Mina Urgan'a göre "Fransız Devrim’inin toplum düzeninde yaptığı değişikliği, Romantizim yerleşmiş kurallara ve biçimlere, geleneksel duygulara ve düşüncelere, kalıplaşmış dile ve anlatıma karşı çıkarak edebiyat alanında yaptığına göre, Romantik akımla Fransız Devrimini birbirinden ayırmanın yolu yoktur" (Urgan, 2019, s. 504). Urgan, romantik akımın yarattığı kargaşayı engellemek için İngiliz Edebiyat Tarihi kitabında şöyle bir açıllama yapar: "Romantizm terimi" "romance" sözcüğünden türemiştir. "Romance" sözcüğ̈̈ gerçeklere uymayan heyecan verici öykülere verilen bir isimdi. Roma İmparatorluğuna bağlı topraklarda konuşulan Fransızca, İtalyanca, İspanyolca, Portekizce gibi Latinceden türeyen dillere Fransızcada "langues romanes", İngilizcede "romance languages" ifadeleri kullanılırdı. Bilim, dil, felsefe ya da ahlakla alakalı ciddi konuları ele alan çoğu yazılar Latince olarak kaleme alınırdı. Halkın benimsediği dillerde yazllan öyküler ve şiirler ise çoğunlukla olağanüstü maceraları ele aldığı doğanın güzelliklerine yeni bir yer verdiği için "romantik" sözcüğü bir süre sonra bu gibi ögelerle özdeşleşti; alışlagelmedik olayları, doğanın değişik görüşlerini anlatmak amacıyla kullanılan bir sıfat haline geldi. Romantik diye tanımlanan şairler kendilerine 'romantik' demezlerdi hatta çağdaşları da onları bu şekilde adlandırmazdı. Jean-Jacques Rousseau gölün kıyılarını betimlerken sadece bir kez "romantik" sözcüğünü kullanır (Urgan, 2019, s. 502).

Romantizm akımın ortaya çıkışı ve "romantizm” kavramının kullanımı ile ilgili olarak 1780'li yıllarda başladığı daha sonra Fransız devriminin bir etkisi sonucu hareketlenerek 19. Yy. başlarında zirveye ulaşmıştır. 18. yüzyılın sonlarına doğru, bir grup Alman yazar, "romantizm" kavramını klasisizmin karşı bir sav olarak kullandıkları, Klasisizm’in, bireyin akıl ve düşünce sistemini temel aldığı, "romantizm" akımının ise bireyin iç dünyasını, coşku ve hayal gücünü ortaya çıardığı bilinmektedir (Altun \& Bölükmeşe 2021, s. 650).

İngiliz edebiyatında romantizm akımı, pre-romantik olarak kabul edilen Thomas Gray, Robert Burns'un şiirleriyle başlamakta ama gerçek Romantik dönemde bulunan arasında İngiltere'nin kuzey batısındaki göller bölgesinde bir süre birlikte yaşamaları sebebiyle Lakistler (Gölcüler) diye anılan William Wordsworth, Samuel Coleridge'tir. Lakistlerin dışında Lord Byron, Percy Bysse Shelley ve John Keats İngiliz edebiyatının romantik döneminde yer alan en önemli romantik şairlerdir (Kolcu, 2003, s. 251).

XVIII. yüzyılın son otuz yılını içeren ve Romantik akımı hazırlayan Pre-Romantik Çă̆ Romantizm'le birlikte değerlendirmek daha uygun olur. Romantik Çağ 1798'de Wordsworth ile Coleridge'in The Lyrical Ballads'ının yayına girmesiyle başlar ve XIX. yüzyılın hemen hemen ortalarına kadar devam eder (Urgan, 2019, s. 502).

Romantizm akımının diğer milletlerin etkileşimi açısından açılamaya çalışan Mina Urgan, İngiliz Edebiyatında Romantizmin ortaya çıkışı şöyle açılar:

Eski İngiliz şiirinde denizle ilgili kenning’lerin (eğretileme-birleşik sözcük) ayrıca bol olmasını doğal karşlamalı. Çünkü savaşın her çeşidinin başlıca temalardan biri olduğu bu şiirlerde denizlerle savaşım ön planda gelir. Edebiyat tarihçisi George Sampson'un dediği gibi, fırtınalarda azgınlaşan buzlu denizlerde geçen gecelerin karanlığı çökmüştür Eski İngiliz şiirinin üstüne. Germenler denizle içli dışlıydılar; IV. yüzyıldan beri tehlikeli denizleri aşarak, Ren Nehri'yle Jutland yarımadası arasındaki anayurtlarından ve Kuzey Denizi kıyılarından Büyük Britanya adalarına akın akın gelmişler; gücünü yitiren Roma İmparatorluğu bu sömürgelerini koruyacak halde olmadı̆̆1 için oralara yerleşmeye başlamışlardı. Yeni yurtları tıpkı eski yurtları gibi yağmurlu, sisli ve soğuktu. Onun için doğanın ancak kasvetli ve korku uyandıran yanları yansır Eski İngiliz şiirine. Germenler

RumeliDE Dil ve Edebiyat Araştırmalar Dergisi Osmanağa Mahallesi, Mürver Ciçeği Sokak, No:14/8 Kadıköy - ISTANBUL / TÜRKIYE 34714 e-posta: editor@rumelide.com tel: +90 505 7958124, +90 2167730616

\section{Address}

RumeliDE Journal of Language and Literature Studies

Osmanağa Mahallesi, Mürver Çiçeği Sokak, No:14/8

Kadıköy - ISTANBUL / TURKEY 34714

e-mail: editor@rumelide.com,

phone: +90 505 7958124, +90 2167730616 
çiçekli yeşil çayırlardan, mırıldanarak uslu uslu akan derelerden, kuşların cıvıldadığı güneşli mavi göklerden söz etmezler; uğuldayan karanlık ormanları, yalçın kayalıkları, fırtınalı denizlerde uçuşan martıları anlatırlar. Ancak Norman istilasından, yani XI. yüzyıldan sonra, Fransız etkisiyle doğaya bakış açısında bir değişiklik oldu; doğanın aydınlık ve huzur verici yanları da şiirlerde ele alındı. Ne var ki, doğa konusunun işlenmesi açısından İngiliz edebiyatının verimli dönemi olan Romantik Çağ'ın şiirlerinden de anlaşılacağı gibi, İngilizler doğanın insanda dehşet uyandıran karanlık yanlarına, ataları Germenler kadar bağlı kalmışlardır bir bakıma (Urgan, 2019, s. 20).

İngiliz Romantik döneminin başlangıcı ve bitişi çok da belirgin olmayıp keskin başlangıç ve bitiş tarihi olmamakla birlikte Klasik dönem sonrası Viktorya dönemi içine girmiş girift bir dönem olarak anılmaktadır. Bu nedenle "romantik" terimi, söz konusu romantik dönemin başlangıcına kadar yaygın olarak kullanımına rastlanılmamıştır. Geleneksel olarak edebiyat tarihçileri, İngiliz Romantik dönemini 1790 yıllarında başlayıp 1830 veya 1840 yıllarında sona erdiğini ifade ederler. Ancak Harold Bloom'a göre akımın asla son bulmadığı tarih yoluyla günümüzde halen yansıtıldığını ifade etmektedir (Volceanov, 2007: 152). Benzer şekilde Ronald Carter ve John McRae, Romantik dönemin başlangıç ve bitiş tarihinin kesin olarak bilinmediğini "Romantik" teriminin söz konusu olan tarihlere kadar çok sayıda kişi tarafından yaygın olarak kullanılmadığını (Carter \& McRae, 1997, s. 217) ifade etmektedir.

Ancak başlangıcın temellerini atan 'ballad' türü olmuş olup bu konuda ilk olarak Wordsworth ve Coleridge'i görebiliriz. Mina Urgan İngiliz Romantizminde Ballad'ların önemini şöyle açıklamıştır. "İngiltere'de edebiyat çevreleri, XVIII. yüzyılın ikinci yarısına değin Ballad'ları genellikle hiç önemsemezler, bu çok ilginç halk şiirlerini, barbar çağların kalıntıları sayarlardı. Gelgelelim Romantik akımın ilk belirtileri görülür görülmez, ballad'lara karşı büyük bir ilgi duyulmaya başlandı" (2019: 15). Romantik dönem, günümüzde tarihin çok önemli bir periyodu olarak görülmektedir. Hâlâ modern dünyanın kalbinde yer alan birçok çatışmayı ve ideolojik tartışmayı bünyesinde barındırmaktadır: Siyasi özgürlük/baskı, bireysel ve kolektif sorumluluk, eril ve dişil roller (son zamanlara kadar Romantizmin geleneksel kanonu neredeyse yalnızca erkek yazarlara aitti), geçmiş, şimdi ve gelecek (Carter \& McRae, 1997, s. 223).

Erkekler ve kadınlar arasındaki sevgi veya potansiyel olarak sevgi dolu ilişki veya dünyayı olduğu gibi görmek ya da görmezden gelmek dünyaya daha geniş vizyoner bakmanın algılamanın bir yoludur. 17701848 yılları arasında Britanya'da ve tüm Avrupa'da gerçekleşen edebi bir hareket/akım ve algıda derin bir değişim Romantik sözcüğü, Latince yazılmış Orta çă̆ şövalyeleri masallarına gönderme yapmaktadır. Bu hikayeler genellikle bir şövalye ve hanımı arasındaki aşk hikayelerini içermekteydi bu da romansın modern anlamıyla ortaya çıkmasıydı. Edebiyatta Romantik dönemden bahsederken, aslında romantizmi "özgürce yaratıcı kurgu" olarak görmek demektir, sıkça karıştırılan "romantik aşk" ta ki romantik değil. Edebiyatta ve görsel sanatlarda, bireysel sanatçının hayal gücünü, duygularını ve yaratıcılığını vurgulayan bir stil olarak karşımızı çıkmaktadır. Romantizm ayrıca, 18. yüzyıl klasisizminin aksine, özellikle 18. yüzyılın sonları ve 19. yüzyılın başlarında Avrupa kültürüne atıfta bulunur. Entelektüel olarak Aydınlanma dönemine şiddetli bir tepki olarak ortaya çlktı. Romantik Dönem, sadece İngiliz edebiyatında değil Avrupa'nın tüm kültürlerinde ortaya çıkış güçlü bir akım olup İngiliz edebiyatında 'Age of Revolutions'- Devrim Çağı olarak bilinir (Alexander, 2000, s. 224).

Amerika’nın Bağımsızlık Bildirgesi 1776'da imzalanmasıyla Britanya Krallığının Kolonyalizmini ve emperyalizmini derinden etkileyerek değiştirdi. 1789 yllında Fransız Devrimi'nin siyasi, politik ve ideolojik (fikir) devrimi yaratması, Napolyon'un 1799 yılında iktidarı ele geçirmesi Avrupa'da işgale başlaması ve krallığa dönüşmesi (1804) ardından da 1815 yılında Waterloo savaşında Fransa'nın

\begin{tabular}{r|l} 
Adres & Address \\
RumeliDE Dil ve Edebiyat Araşttrmaları Dergisi & RumeliDE Journal of Language and Literature Studies \\
Osmanağa Mahallesi, Mürver Çiçeği Sokak, No:14/8 & Osmanağa Mahallesi, Mürver Çiçeği Sokak, No:14/8 \\
Kadıköy - İSTANBUL / TÜRKIYE 34714 & Kadıköy - ISTANBUL / TURKEY 34714 \\
e-posta: editor@rumelide.com & e-mail: editor@ rumelide.com, \\
tel: +90 505 7958124, +90 216 773 0 616 & phone: +90 505 7958124, +90 2167730616
\end{tabular}


egemenliği Britanya tarafından yenilgiye uğramasıyla sona ermiştir. ${ }^{6}$ 18.yy'da Endüstriyel devrimin gerçekleşmesi 19. yüzyılın başlarında ekonomik, kültürel ve sosyal yapıda devrimlerin yaşanması oldukça önemlidir.

Ekonomik açıdan büyük değişimlere Romantik dönemin dayanak noktası olup ekonomiye yön veren üst sinıf topluma ve iktidara dönük yeni bir perspektif oluşmuştur. Adam Smith tarafindan ortaya atılan 'Laissez Faire" olgusunun The Weatlh of Nations (Uluslarm Zenginliği) eserinde bahsedildiği terimin ilkesiyle Britanya'nın sosyal yapısında işçi-çalışan sınıfında değişim, ulaşım ve ticarette yeni değişimler başladığı bilinmektedir. Ulaşımla birlikte kısa sürede insanların ve fikirlerin yolculuğu gerçekleşmiştir. Siyasi olarak Amerika ve Fransa'daki devrimlerden ve Polonya, İspanya, Yunanistan ve diğer yerlerdeki popüler bağımsızlık savaşlarından esinlenmiştir. Duygusal açıdan aşırı bir benlik iddiasını ve bireyin değerini ifade etmektedir. Deneyim, tecrübe ('egoistical sublime'), sonsuz ve aşkıncllı (Infinite Transcendantal) duygusuna eşlik etmiştir. Romantik şairler ve yazarlar sosyal olarak ilerici nedenleri savundular, ancak bunlar hayal kırıklığına uğradıklarında acı üreterek kasvetli ve umutsuz bir görünüm ortaya çıkmıştır.

Romantik döneme ait sanat ve edebiyatta; atmosferik manzara sevgisi, geçmişe, özellikle de Gotik'e olan nostalji; halk gelenekleri dahil ilkel aşk, bireysel kahraman figürünün kültü, genellikle bir sanatçı veya politik devrimci; Romantik tutku, Mistisizm ve ölüme duyulan hayranlık bulunmaktaydı. Romantik hareket, mutlak özgünlük ve sanatsal ilham fikrini, "yokluktan yaratma" gerçekleştiren bireysel deha ile ortaya çıktı. Duygusal meseleyi yaratıcı bir biçimde tasvir eden edebiyat "edebiyatta liberalizm" hayal gücü, duygu ve özgürlük kesinlikle romantizmin odak noktalarıdır. Romantizm bireyin kendini ifade etmesi, (Self-Expressionism-öz anlatım) ve bireysel benzersizlik üzerine odaklanır (Volceanov, 2007, ss. 153-154). Jean Raimond'a göre Blake tarafından yayınlanan Masumiyet Şarkıları ilk yayınlandığında hiç ses getirmemişti ancak bir süre geçtikten sonra romantik yapılar olarak algılanmaya başlandı. “İngiltere'de Orta çağın çekiciliği, doğa sevgisi, egzotizim açlığı, doğaüstü arayışı, özgürlük özlemi, (bütün İngiliz Romantikleri Fransız devrimi etkisi altında kalmıştır) imgelemenin akla baskın çıması, simgelerin ve mitlerin büyüsü, Spenser, Shakespeare ve Milton'la güçlü bağlantılar kuran Romantizmin en belirgin özeliklerindendir" (Raimond, 2019, s. 77).

İngiliz Romantik dönem edebiyatında çıkan eserleri klasik ve akıl çağına dönük bir karşılaştırma sunulacak olursa, The Age of Reason-Akıl Çă̆'ında Akıl-muhakeme, evrensel deneyim, bir bütün olarak toplumun değeri, toplumsal değer ve kurallar, akla inanç, kentsel topluma ilgi, halka açık ve kişisel olmayan şiir, bilimsel ve sıradan olanla ilgilenme söz konusu iken Romantik dönemde, hayal gücü ve duygu, belirli bir deneyime odaklanma, bireysel açıdan insana ve özgürlüğe değer, duyulara, duygulara, hayal gücüne inanç, kırsal ve doğal alanlara, öznel şiir, gizem ve sonsuzluğa ilgi söz konusudur. Bu açıdan incelendiğinde Akıl Çağ’ ve Romantik dönem arasında keskin bir çizgi ve ayrım söz konusu olmakta bu dönemin sanat ve edebiyat türüne özellikle şiire derin bir şekilde yansımaktadır.

İngiliz Romantik edebiyatı ezici ve baskın bir şekilde şiirseldi. 19. yüzyılın başlarında edebiyatta iklimi değiştirdi (Alexander, 2000, s. 218). Wordsworth, yeni şiirin ruhunu lirik baladların öncesinde hazırlamaya çalıştı (1800, 1802). Şiir, "güçlü duyguların spontan taşması” olarak görülmüştür; şiirin özü (dış dünyanın değil) akıl, duygu ve şairin hayal dünyası idi. Birinci kişilik söz şiiri, "Ben” doğrudan şaire atfedilmiştir (Compton-Rickett, 2012, s. 79). Benliğin gelişimi romantik şiirin başlıca konusu oldu. Şairler kriz zamanı kendilerini peygamberler/kâhin olarak gördü, dünya üzerindeki bir "cennet" açısından kutsal bir arınma ve kefaret sözü tashih edilirdi. Şiir kompozisyonunun ilk hareketi

https://www.history.com/topics/british-history/battle-of-waterloo adresinden alındı. Erişim Tarihi: 20.09.2021. 
içtepi/dürtü ile doğmalıdır; geçmişten gelen kurallardan kurtuluşun ve içgüdü, sezgi ve duyguya güvene dayanmaktaydı. Düşünmeye ve kişisel problemlerin ve krizlerin çözümüne uyarıcı olarak hizmet veren vahşi doğanın doğru gözleminin önemi ve açıklaması mevcuttur. Doğa, Tanrı'nın doğasını gösteren semboller sistemi olarak görülür. Doğa insanlığın doğal iyiliğini ortaya çıkarmak olarak görülür.

İngiliz Romantikler yaratıcı özgürlüğü geliştirdiler. Çeşitli şiirsel biçimler kullanmışlardır. Toplumdaki insanın duygularının aksine, yalnızlıktaki insanın duygularını ifade etme eğiliminde idiler. Blake dışında tüm şairler doğal ortamı tanımladılar. Romantikler’in dili 18. yüzyıl şairlerinden daha özgür ve gayri resmi kullanma eğiliminde idiler. Fransız Devrimi'nin büyük tarihsel gerçeğinden derinden etkilendiler ve Romantik şairler hem hayata hem de sanata oldukça yakından ilgilendiler.

\section{The Ecchoing Green (Yankuyan Yeşillik) şiirinde romantik öğeler}

The Ecchoing Green, William Blake'in 1789'da Songs of Innocence'ta yayınlanan bir şiiridir. Şiirde dışarıda oynayan çocuklara eşlik eden neşeli sesler ve imgeler yer almaktadır. Kuş cıvıltısı ve çıngırakların işaret ettiği bahar gelişi ve çocukların köyün doğasında yer alan yeşilliklerinde oynamaktadırlar. Yaşlı erkekler ve kadınlar çocukları izlemekten zevk alır ve kendi çocukluklarını hatırlar. Sonunda çocuklar yorulur, güneş batar ve çocuklar dinlenmeye geçer. Şiir, aslında Song of Innocence -Masumiyet Şarkıları'nda yer alan pastoral temayı sahip, doğa ile insan arasındaki uyum ve genç ile yaşlı arasındaki uyuma dem vurmaktadır. Üçüncü şahıs tarafından anlatılan (muhtemelen şair) şiirde, sıradan bir günde geçen olayları izleyen kişinin, insan yaşamının tüm döngüsünü, öngörüsünde bulunduğu karanlık gelecek kehanetiyle bağdaştırdığı görülmektedir.

Şair çocukları bekleyen olumsuzlukları doğa ve estetik bir görünüme sahip manzarayla şiirsel olarak anlatmaktadır. Şiirin son dörtlüğünde sürecini tersine çevirmeye çalıştı̆̆ı izlenmektedir. Sarmal olarak günün her biri diğerini tetiklediği bir nevi enerji ve sevinç/mutlulukla doğması yerine günün olumsuzlukla bittiği gözlemlenmektedir. Şiirde geçen bir günde doğa içinde bir araya gelme, eve dönüş geliş ve bunun sonucunda doğal bir yorgunluk gözlemlenmektedir. Tüm bu zaman diliminde şiirde geçen çocuklar doğa içerisinde tıpkı kuşlar gibi zaman ve doğa ile uyum içerisinde olduğu görülmektedir. Ancak son nakaratta, yer alan "Kararan yeşillik" ifadesiyle mistik bir gizem karanlık bir kehanetin gizemi söz konusu olmaktadır. Şiirde iki karşıtlık söz konusu olmaktadır; birincisi doğanın insana (çocuğa) verdiği özgürlük ruhu ve uyum ikincisi karanlık bir gelecekte umutsuzluk ve çaresizliktir. Şaire göre yeşilliğin yani doğanın kararması ile gerçek hayatlarının kararacağı bir nevi ölüme benzetme yapıldığı gözlemlenmektedir, ancak yaşlı neslin geçmişe özlemle bakması doğadaki güzellikleri, oynadıkları oyunları ve doğada geçirdikleri zamana atıfta bulunması aslında sanayi devrimi ile değişen dünyaya bir gönderme olarak anılmaktadır.

William Blake’in kehanet görüsü olarak yazdığı dizeler aslında birçok araştırmacının çalışma konusu olmuştur. "Blake, bunları "Ozan! (Bard) / Kim? Şimdiki zamanda, Geçmişte ve Geleceği gören" kişiliğinde veya "ses”i ile yani, Spenser'ı ve özellikle de Milton’ı İncil'in peygamberleri izleyen bir İngiliz şair olarak yazdı" Aslında yazdıkları bir şair olarak kendi deyimiyle "Çalışmamın doğası" “öngörüsel veya hayal ürünüdür” açıklanabilir. (Greenblatt \& Abrams, 2005, s. 77). Kendisi bir vizyoner/kâhin/ozan edasıyla geleceği görerek göndermede bulunmaktadır. Cıvıl cıvıl renkler, ışık, kuş sesleri, bahar, yeşillik, çan sesleri, gülüşmeler kahkahalar ve çocukların masum mutluluğu pastoral bir cennet edası yaratmakta ve "yankıyan yeşillik" ile adlandırılmaktadır. Bu şiirinde Blake, masumiyetin deneyim kazandığını ifade etmek için çocuk ve doğa temasını kullanmaktadır. Aslında her iki kavramda masumiyeti güzelliği ve mutluluğu ifade etmektedir. Ancak sanayi devrimiyle kirletilmekte ve karartılmakta olan doğayla 
yaşamların karardığına dikkat çekmeye çalışmaktadır. Blake, masumiyet ve deneyimin açısından Romantik geleneğinde önemli ve benzersiz şairler arasında yer almaktadır.

Çocuk kavramı insan zihnindeki en hassas ve cesur sezgilerin sembolüdür. Romantizmin unsurları bu şiirlerde mevcuttur, bazıları en üst düzeyde, örneğin merak duygusu, yeni gözlerle doğanın tefekkürü, varoluş biçimlerine duyulan samimi bir sempati örneğidir. Doğa ve insan dünyası, ilham verici bir vizyonla mucizevi bir şekilde koruyan bir şairin zevk aldığı sevgi, güzellik ve masumiyet dünyasını andırmaktadır. Şiirde temel olarak öne çıkan "ilkbahar", "oyun” ve yeşillik kavramları oldukça önem arz etmektedir.

Blake'in aslında Masumiyet ve Tecrübe Şarkıları olarak ele aldığı eserin bir parçası olarak şiirinde ilkbahar kavramı ile büyüme/olgunlaşma ve yeniden doğma ile alakalı bahar imajını kullandığı düşünülmektedir. Çünkü Blake, insan ruhunun iki zit durumunu bir araya getirmektedir. Baharda cıvıldayan kuş sesleri, çiçeklerin yeniden çiçek açması yeniden doğuşun sembolüdür. Bu kavramlar doğal pastoral ortamı ve bozulmamış olanı temsil etmektedir. Bozulmayan insanoğluna yani mutlu bir çocukluğa işaret etmektedir. Bu nedenle bahar tıpkı çocukluk gibi masumiyet barındırmaktadır. Oyun kavramı ile baharın gelişi ve çocukların oyun oynaması ilişkilendirilmiştir. Çocuklar baharın gelişi ile doyasıya oynar, çiçek gibi doğal ve özgürdürler. Oyun çocukluk çağını ifade eder ve yaşlı bireye geçmişini hatırlatır. Yeşil ve yeşillik kavramları yine bahar ile ilintili olmakla beraber doğayı sembolleştirmektedir. Yeşil aslında olgunlaşmanın büyümenin ve tecrübenin bir sembolü olarak ifade edildiği görülmektedir. Yeşil pozitif duygular barındıran çocukluğun hayal dünyasının ve gücünün önemine işaret etmektedir. Doğa ve yeşillik aslında kimseye ait olmayan özgür bir alan/toprakları ifade etmektedir. Burada herhangi bir baskı otorite veya kural söz konusu değildir. Ancak Sanayi devrimi ile bu alanlar artık kirletildiği ve karartıldığı öngörüsü ile değişime uğradığı vurgusu yapıldığı düşünülmektedir.

Tematik açıdan şiir aslında doğanın ve yeşilliğin sunmuş olduğu doğallık içeresinde özgürce kuşlar gibi hareket eden masumiyete atıfta bulunmaktadır. Doğal ve insani özelliklerin ön planda olduğu pastoral bir yaşam vurgusu söz konusudur. İhtiyar, yaşl, genç ve çocuk demeden herkesin birlikteliğinin garantörü olan doğanın hâkim olduğu bir ortam söz konusudur. Şiirde vurgu genellikle mutluluğu ifade eden "mutluluk "neşe" "sevinç" vb. sözcükler üzerinedir. Yaşlıların altında oturduğu meşe ağacı da bir tecrübe sembolü olarak kullanılmıştır. Eski ve yeni nesil arasında pek bir değişimin olmadığını benzer manzaraların, oyunların ve sevinçlerin olduğu ifade edilmiştir. Ancak çocuk masumiyetinin çok uzun sürmeyeceğini ruh halini karartan bir dizeyle şiire son vermektedir.

\begin{tabular}{|c|c|}
\hline The Ecchoing Green & Yankıyan Yeşillik \\
\hline The Sun does arise, & Güneş doğup yükseliyor, \\
\hline And make happy the skies. & Gökleri mutlu ediyor. \\
\hline The merry bells ring, & Çalıyor neşeli çanlar, \\
\hline To welcome the Spring. & Baharı karşılıyorlar. \\
\hline The sky-lark and thrush, & Tarlakuşları, ardıçkuşları, \\
\hline The birds of the bush, & Çalılığın kuşları, \\
\hline Sing louder around, & Çanların şen seslerinin \\
\hline To the bells chearful sound, & Çevresinde daha yüksek sesleri, \\
\hline While our sports shall be seen & Oyunlarımız görüleceğinde \\
\hline On the Ecchoing Green. & Yankıyan Yeşillikte. \\
\hline $\begin{array}{r}\text { Adres } \\
\text { RumeliDE Dil ve Edebiyat Arasttrmalarm Dergisi } \\
\text { Osmanağa Mahallesi, Mürver Ciçĕgi Sokak, No:14/8 } \\
\text { Kadıköy - İTANBUL / TÜRKIYE } 34714 \\
\text { e-posta: editor@rumelide.com } \\
\text { tel: +90 505 7958124, +90 216 773 o } 616\end{array}$ & $\begin{array}{l}\text { Address } \\
\text { RumeliDE Journal of Language and Literature Studies } \\
\text { Osmanağa Mahallesi, Mürver Ciçeği Sokak, No:14/8 } \\
\text { Kadiköy - ISTANBUL / TURKEY } 34714 \\
\text { e-mail: editor@rumelide.com, } \\
\text { phone: +90 505 7958124, +90 } 216773 \text { o } 616\end{array}$ \\
\hline
\end{tabular}




\begin{tabular}{|l|l|}
\hline Old John with white hair & İhtiyar John ak saçıyla \\
\hline Does laugh away care, & Gülüp geçer kaygllara, \\
\hline Sitting under the oak, & Oturmuş meşenin altına, \\
\hline Among the old folk. & Yaşlların arasına. \\
\hline They laugh at our play, & Oyunumuza gülüyorlar, \\
\hline And soon they all say, & Peşinden şöyle diyorlar, \\
\hline Such such were the joys, & Bizim de böyleydi sevinçlerimiz, \\
\hline When we all girls \& boys, & Oğlan iken kız iken biz hepimiz, \\
\hline In our youth time were seen, & Görülürdü küçüklük devrimizde, \\
\hline On the Ecchoing Green. & Yankiyan Yeşillikte. \\
\hline Till the little ones weary & Ta ki yorulup çocuklar, \\
\hline No more can be merry & Keyifleri kaçana kadar \\
\hline The sun does descend, & Güneş alçalıp batıyor, \\
\hline And our sports have an end: & Oyunlarımız bitiyor: \\
\hline Round the laps of their mothers, & Analarının kucağında \\
\hline Many sisters and brothers, & Kuzlar oğlanlar bir arada, \\
\hline Like birds in their nest, & Tipki yuvada kuşlar, \\
\hline Are ready for rest: & Dinlenmeye hazırlar: \\
\hline And sport no more seen, & Ve artık oyun görülmez, \\
\hline On the darkening Green & $\begin{array}{l}\text { Kararan Yeşillikte. } \\
\text { Çeviri: Selahattin Özpalabıylklar (İnal, 2019). }\end{array}$ \\
\hline
\end{tabular}

\section{Sonuç}

On sekizinci yüzyılın sonlarında ve On dokuzuncu yüzyllın başlarında Avrupa kültüründe Romantizm akımının temsilcisi olarak lirik, mistik ve vizyoner Blake'in şiirleri ve sanat eserleri geniş bir yankı bulmuştur. Şiirinde birçok stili bir arada barındırdığı doğa, çocuk, özgürlük ve sevinç gibi romantik öğelerin yer aldığı görülmüştür. Blake' in aynı zamanda imgeler, semboller, metaforlar ve özgürlükçü ruhu ile duygu ve düşüncelerini spontane bir şekilde dile getirdiği tespit edilmiştir.

Blake, klasik yaklaşımda derin çatlaklar yaratarak yaşadığı dönemin ve ortamın özgürlükçü ve insani değerleri samimi bir şekilde şiirlerine yansıtmıştır. Blake eserinde çocukluk dönemine verdiği önemi vurgulayarak mutluluk, doğa, bahar ve yeşillik gibi kavramları ön plana çıkarmaya çalışmıştır. "Yankılanan" yeşilin "kararan" yeşile dönüştüğü son dörtlükte bir melankoli esintisi şiirde izlenmektedir. Şiirde yer alan masumiyetin ve hayal gücünün sunmuş olduğu mutluluk ve sevinç her ne kadar ilkbahar ile pekiştirilse de bu ortamın böyle sürmeyeceği düşüncesi karanlık bir kehanet ile sona ermektedir.

William Blake bu şiirinde Romantik Çağ’’n ana temalarından biri olan doğaya dönüşü oldukça belirgin bir şekilde sunmuştur. Doğa tüm canlılar için bir özgürlük alanıdır. Doğuşun, büyümenin, tecrübenin ve masumiyetin bir sembolüdür. Çocukluğun, yaşamanın ve yaşlanmanın resmedildiği bu şiirde Blake aslında sadece melankolik öngörünün yanı sıra yaşam döngüsüne de atıfta bulunmuş, doğanın üstünde bir otorite tanımamıştır. Her ne kadar eserini basit, tekdüze bir üslupla kaleme alsa da kullandığı imge

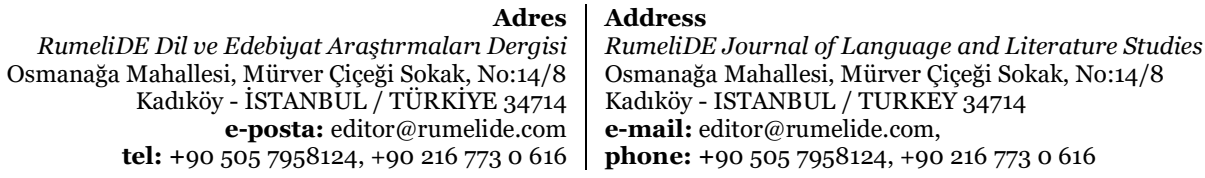


ve sembollerle sosyal mesajlar verdiği görülmektedir. Nitekim Blake’in imgeler, semboller, metaforlar ve özgürlükçü ruhuyla duygu ve düşüncelerini spontane şekilde birleştirerek sunması onu romantik akımın özelliklerine olan bağlılığını ayrıca göstermektedir.

\section{Kaynakça}

Ackyord, P. (1995). Blake A Biography. New York: Ballantine Books.

Aksakal, H. (2015). Politik Romantizm ve Modernitenin Eleştirileri. İstanbul: Alfa.

Alexander, M. (2000). A History of English Literature. London: Macmillan.

Altun, S., Bölükmeşe, E. (2021). Gürcü Romantizminde Nikoloz Barataşvili’nin “Tulpar”. Uluslararası Türkçe Edebiyat Kültür Eğitim Dergisi 10/2, 649-66o.

Bentley, G. E. (1975). William Blake:The Critical Heritage. London-New York: Routledge.

Bentley, G. E. (2001). The Stranger from Paradise: a biography of William Blake. New York: Yale University Press.

Carter, R., \& McRae, J. (1997). The routledge History of Literature in English Britain and Ireland. London-Newyork: Routledge.

Compton-Rickett, Ar. (2012). A History of English Literature. London: Dodge Publishing.

Fletcher, R. H. (2002). A History of English Literature. Blackmask Online.

Greenblatt, S., \& Abrams, M. H. (2005). The Norton Anthology of World Literature: Volume 2. New York: W.W. Norton\&Company.

İnal, A. A. (2019). William Blake Musumiyet ve Tecrübe Şarkıları. İstanbul: Türkiye İş Bankası Kültür Yayınları.

Kaya, M., Kardaş, M. N. (2019). İngiliz Edebiyatı. O. Sevim, \& Y. Söylemez içinde, Dünya Edebiyatı Araştırmaları (s. 79-104). Ankara: Nobel.

Kolcu, A. İ. (2003). Batı Edebiyatı. Ankara: Çağ.

Löwy, M., \& Sayre, R. (2015). İsyan ve Melankoli Moderniteye Karşı Romantizm (Çev: Işılk Ergüden). İstanbul: Alfa.

Pheleps, W. L. (2012). The Beginnings of The English Romantic Movements A Study in Eighteen English Literature. London: Forgotten Books.

Raimond, J. (2019). İngiliz Edebiyatı . Ankara: Dost .

Urgan, M. (2019). İngiliz Edebiyatı Tarihi. İstanbul: YKY.

Volceanov, G. (2007). A survey of English Literature From Beowulf to Jane Austen. Bükreş: Spiru Haret Universitesi. 